\title{
Association of $C D 36$ expression and polymorphism with serum biochemical indices in Cherry Valley duck
}

\author{
D.D. Wang, W.G. Li and Y.Y. Zhang \\ Key Laboratory of Animal Genetics, \\ Breeding and Reproduction in the Plateau Mountainous Region, \\ Ministry of Education, College of Animal Science, Guizhou University, \\ South Campus, Huaxi, Guiyang, Guizhou, China \\ Corresponding author: Y.Y. Zhang \\ E-mail: zyy8yyc@163.com \\ Genet. Mol. Res. 15 (2): gmr.15027994 \\ Received November 5, 2015 \\ Accepted February 12, 2016 \\ Published May 23, 2016 \\ DOI http://dx.doi.org/10.4238/gmr.15027994
}

ABSTRACT. Cluster of differentiation 36 (CD36) plays a crucial
role in lipid sensing, innate immunity, atherogenesis, and glycolipid
metabolism. This aims of this study were to delineate the CD36 mRNA
expression profile in 16 duck tissues using relative quantitative real-
time PCR and to screen single nucleotide polymorphisms (SNPs) in the
duck CD36 gene by PCR-single strand conformation polymorphism and
DNA direct sequencing. In addition, this study investigated CD36 gene
expression, genetic variation, and their effect on serum biochemical
indices in duck. The results showed that $C D 36$ mRNA was expressed in
all tissues, and was highly specific to the pituitary and large intestine, and
to subcutaneous and abdominal fat. Furthermore, three genotypes of the
SNP g.476593 T $>$ C in exon 9 of the duck CD36 gene were identified:
MM, MN, and NN. The dominant genotype and allele were MM and
M, with frequencies of 0.453 and 0.643 , respectively. The genotype
distributions deviated from Hardy-Weinberg equilibrium $(\mathrm{P}<0.05)$ and
achieved moderate levels of polymorphism in ducks. Correlation results 
showed that $C D 36$ mRNA was significantly negatively correlated with triglycerides $(\mathrm{P}<0.05)$, and significantly positively correlated with total protein, globulin, low-density lipoprotein cholesterol, and total cholesterol $(\mathrm{P}<0.01)$. All serum biochemical indices measured, with the exception of triglycerides, in birds with the NN genotype were significantly higher than those in birds with the MM genotype. These findings demonstrated that $C D 36$ might be an important genetic marker for the selection of lipid metabolism and meat quality traits in ducks.

Key words: $C D 36$; Gene expression; Genetic variation; Serum biochemical indices

\section{INTRODUCTION}

Cluster of differentiation 36 (CD36), an integral membrane glycoprotein, is broadly expressed on the surface of different cell and tissue types, including hepatocytes and apoptotic, kidney, heart, adipose, retina, small intestine, tongue, skeletal, and vascular muscle cells (Kwok et al., 2007; Cho, 2012; Primeaux et al., 2013). CD36 is classified as a class B scavenger receptor which is composed of scavenger receptor B1 (SR-B1) and the lysosomal membrane protein2 (LIMP2) (Pepino et al., 2014). Among the class B scavenger receptors, $C D 36$ was initially cloned. It is thought that $C D 36$ participates in a range of physiological and pathological processes related to lipid sensing, innate immunity, atherogenesis, and metabolism (Febbraio et al., 2001; Silverstein and Febbraio, 2009). This occurs as a result of its ability to bind to a host of ligands, such as native and oxidized lipoproteins, fatty acids, hexarelin, and collagen (Nergiz-Unal et al., 2011). CD36 has been extensively studied since its identification as a receptor for thrombospondin-1 in 1989. Initial evidence supported a role for CD36 in internalization (Endemann et al., 1993; Ryeom et al., 1996) and later evidence proposed that it also plays a part in signal transduction. Up to now, significant achievements have been made with the new acquaintance of $C D 36$.

Bao et al. (2012) reported that $C D 36$ expression is suppressed in hyperlipidemic ApoE knockout mice treated with salvianolic acid B (SAB), a potential antiatherogenic molecule for the treatment of atherosclerosis and other inflammatory and/or vascular diseases. CD36 variants in African Americans have been associated with a protective metabolic profile and increased disease susceptibility (Love-Gregory et al., 2011). A recent study suggested that the plasma membrane fatty acid transporter CD36 plays a crucial role in exercise performance, muscle fuel selection, and training-induced muscle fatty acid oxidation (FAO) adaptation, challenging long-held opinions about mechanisms involved in adaptive and acute regulation of muscle FAO (McFarlan et al., 2012). CD36 expression is regulated at the transcriptional level by adhesion, cytokines and nuclear hormone receptors (Prieto et al., 1994; Huh et al., 1996). For example, the nuclear hormone receptor peroxisome proliferator-activated receptor gamma (PPAR $\gamma$ ) and the cytokines oxidized low-density lipoprotein (oxLDL) and interleukin-4 (IL-4) are known to upregulate $C D 36$ expression. Evidence has shown that HIV protease inhibitors contribute to induce $C D 36$ expression in male mice, but have the opposite effect in female mice (Allred et al., 2006). Hepatic CD36 expression in male and female contrasts with the finding what has Allred made under hormonal and nutritional conditions (Cheung et al., 2007). Thiazolidinediones, glucose, and insulin appear to increase CD36 expression in monocytes, 
adipose cells, and macrophages (Forbes et al., 2005; Llaverias et al., 2006; Kolak et al., 2007). However, few studies have been performed on $C D 36$ in poultry. To further our understanding of $C D 36$, this study investigated $C D 36$ in duck. Levels of $C D 36$ mRNA were investigated in 16 different tissues of Cherry Valley ducks using quantitative real-time PCR (qPCR). Single nucleotide polymorphisms (SNPs) in the duck CD36 gene were determined by single-strand conformation polymorphism (SSCP) and direct sequencing, and their effects on duck serum biochemical properties were determined.

\section{MATERIAL AND METHODS}

\section{Animal and sample collections}

Cherry Valley ducks (53 males, 42 females) were hatched on the same day and bred under commercial corn-soybean diets satisfying nutritional requirement criterion (NRC) requirements, under semi-confined conditions in the experimental field of Guizhou University in Guizhou, China. Blood samples $(3 \mathrm{~mL})$ were obtained under aseptic conditions from the jugular vein of each individual and kept at room temperature until serum was isolated in a vacutainer tube after 10 weeks. After blood was collected, ducks were immediately euthanized. Tissues samples were collected from the heart, liver, spleen, lung, kidney, cerebellum, cerebrum, gizzard, proventriculus, large intestine, intestine, subcutaneous fat, abdominal fat, hypothalamus, pituitary, and breast muscle, and stored at $-80^{\circ} \mathrm{C}$ until further use. Ethical approval was obtained from the Departmental Ethics Committee for Research on Animals under reference number R11/37.

Serum biochemical samples, including total protein (TP), albumin (ALB), globulin (GLB), total cholesterol (TC), triglyceride (TG), low-density lipoprotein cholesterol (LDL-C), and highdensity lipoprotein cholesterol (HDL-C) were aliquoted and frozen at $-20^{\circ} \mathrm{C}$ for further analysis or immediately measured by CX4 type full automatic biochemical analyzer (Beckman, USA).

\section{Primer sequences}

Based on the $\beta$-actin gene sequence (GenBank accession No. EF667345) and CD36 gene (GenBank accession No. NW_004676779), 10 pairs of primers (shown in Table1) were designed using the Primer Premier 5.0 software, checked by BLAST and sent to Sangon Biotech (Shanghai) Co., Ltd. to synthesize.

\section{DNA isolation, RNA isolation, and cDNA synthesis}

Genomic DNA was isolated from the blood of individual duck using BloodGen Mini Kit (Beijing ComWin Biotech Co., Ltd., China). Total RNA was extracted from respective tissues using TRIzol Reagent (Invitrogen, USA) in accordance with the experimental protocol. The concentration of DNA and RNA was measured and subsequently adjusted to $60 \mathrm{ng} / \mu \mathrm{L}$ using a Nano-Drop 2000 (USA) and stored at $-80^{\circ} \mathrm{C}$ until use. cDNA was obtained from isolated RNA using a HiFiScript 1st Strand cDNA Synthesis kit (Beijing ComWin Biotech Co., Ltd.) and stored at $-20^{\circ} \mathrm{C}$ until use. Specificity and quality of genomic DNA and total RNA were confirmed by the absence of background PCR products and target band size on $1.2 \%$ agarose gels stained with ethidium bromide. By electrophoresis, single, clear, and bright 
target bands emerged and the $\mathrm{OD}_{260 / 280}$ ratio for all samples was within the range 1.8-2.0, indicating that the DNA was of good quality and that the extracted RNA could be used for further analysis.

\section{Table 1. Primer sequences for PCR.}

\begin{tabular}{|c|c|c|c|c|}
\hline Primers & Sequences $\left(5^{\prime} \rightarrow 3^{\prime}\right)$ & Regions & Product size & $\mathrm{TM}\left({ }^{\circ} \mathrm{C}\right)$ \\
\hline \multirow[t]{2}{*}{ CD1 } & F: GTCTGCACCCTGAAGAAGGA & \multirow[t]{2}{*}{ all Exon1 (g.457702-457878) } & \multirow[t]{2}{*}{177} & \multirow[t]{2}{*}{59.4} \\
\hline & R: CCATCTGGATTGAAAGAGGAA & & & \\
\hline \multirow[t]{2}{*}{$\mathrm{CD} 2$} & F: GTCAGGCTGCCTTCAAATGT & \multirow[t]{2}{*}{ all Exon2 (g.466244-466633) } & \multirow[t]{2}{*}{390} & \multirow[t]{2}{*}{58.5} \\
\hline & R: TTCTGAGCTTTCCAAAACCAA & & & \\
\hline \multirow[t]{2}{*}{ CD3 } & F: TCAGTCAGATGTGTTGACTTGAA & \multirow[t]{2}{*}{ all Exon3 (g.468676-468921) } & \multirow[t]{2}{*}{246} & \multirow[t]{2}{*}{61.0} \\
\hline & R: TGTGCATATTATGGTTTATTTTCTCA & & & \\
\hline \multirow[t]{2}{*}{ CD4 } & F: GCTCACGCAGAATTTTATGCTA & \multirow[t]{2}{*}{ all Exon4 (g.471001-471250) } & \multirow[t]{2}{*}{250} & \multirow[t]{2}{*}{60.5} \\
\hline & R: GCCTTCTGATTGGTTTCACTT & & & \\
\hline \multirow[t]{2}{*}{ CD5 } & F: CAGCTGCAAGGAAGAAAAATC & \multirow[t]{2}{*}{ all Exon5 (g.471290-471538) } & \multirow[t]{2}{*}{249} & \multirow[t]{2}{*}{55.9} \\
\hline & R: GCTCTCAGTGAGCCAGGTCT & & & \\
\hline \multirow[t]{2}{*}{ CD6 } & F: CCAAAGTGACTAAAACATATTGCTCC & \multirow[t]{2}{*}{ all Exon5 (g.475628-475877) } & \multirow[t]{2}{*}{250} & \multirow[t]{2}{*}{61.1} \\
\hline & R: CAGTACCATGCCCCTGCTAT & & & \\
\hline \multirow[t]{2}{*}{ CD7 } & F: GCGCTGAAACAAGGCGTAAT & \multirow[t]{2}{*}{ all Exon9 (g.476528-476759) } & \multirow[t]{2}{*}{232} & \multirow[t]{2}{*}{61.1} \\
\hline & R: AAACATCGCAAGGTTACTGAA & & & \\
\hline \multirow[t]{2}{*}{ CD8 } & F: CAGGGAGTGAGGTCTTCTATGCTG & \multirow[t]{2}{*}{ all Exon12 (g.479035-479284) } & \multirow[t]{2}{*}{250} & \multirow[t]{2}{*}{61.1} \\
\hline & R: AGGACTGAGCCATTAATGTTTACTT & & & \\
\hline \multirow[t]{2}{*}{$\beta$-Actin } & F: GGGTTCAGGGGAGCCTCTGT & & \multirow[t]{2}{*}{170} & \multirow[t]{2}{*}{60.0} \\
\hline & R: AACTGGGATGACATGGAGAAGA & & & \\
\hline \multirow[t]{2}{*}{ CD36 } & F: GCTGCTCGTTTTGAACCTGA & & 163 & 60.0 \\
\hline & R: TGTTCTGCAGCATGGATGAC & & & \\
\hline
\end{tabular}

\section{Real-time PCR detection}

Sequences of all PCR products were confirmed by DNA sequencing. To determine the tissue distribution of duck CD36 mRNA, cDNA was amplified on a C1000 Touch ${ }^{\mathrm{TM}}$ Thermal Cycler (Bio Rad, USA). Relative quantitative real-time PCR was performed in a volume of 20 $\mu \mathrm{L}$ as follows: $1 \mu \mathrm{L}$ cDNA, $1 \mu \mathrm{L}$ forward /reverse primer, $7 \mu \mathrm{L}$ RNase-free $\mathrm{dH}_{2} \mathrm{O}$, and $10 \mu \mathrm{L}$ Ultra SYBR Mixture (with ROX). Three independent experiments were carried out using each sample, each one in triplicate. After initial denaturation for $5 \mathrm{~min}$ at $95^{\circ} \mathrm{C}$, DNA was subjected to further amplification as follows: denaturation at $95^{\circ} \mathrm{C}$ for $30 \mathrm{~s}$, annealing at $60^{\circ} \mathrm{C}$ for $40 \mathrm{~s}$, and extension for at $72^{\circ} \mathrm{C}$ for $40 \mathrm{~s}$. A final extension was performed for $5 \mathrm{~min}$ at $72^{\circ} \mathrm{C}$ after 40 cycles. $\beta$-actin was selected as a housekeeping gene for the normalization of expression.

\section{SNP detection}

Eight pairs of primers (CD1-CD8, as shown in Table 1) were used to identify polymorphism of the $C D 36$ gene. All DNA samples were used for PCR-SSCP analysis. The PCR system consisted of $10 \mu \mathrm{L} 2 \mathrm{X}$ Taq Master Mix ( $p f u$ ) [Sangon Biotech (Shanghai) Co., Ltd.], $7 \mu \mathrm{L}$ free water, $1 \mu \mathrm{L}$ forward primer, $1 \mu \mathrm{L}$ reverse primer, $1 \mu \mathrm{L}$ DNA in a total volume of 20 $\mu \mathrm{L}$. PCR was performed using the following conditions: initial denaturation for $5 \mathrm{~min}$ at $95^{\circ} \mathrm{C}$, denaturation for $30 \mathrm{~s}$ at $95^{\circ} \mathrm{C}$, annealing for $30 \mathrm{~s}$ at the temperature shown in Table 1, extension for $35 \mathrm{~s}$ at $72^{\circ} \mathrm{C}$ (total of $33 \mathrm{cycle}$ ); final extension for $5 \mathrm{~min}$ at $72^{\circ} \mathrm{C}$, preserved at $10^{\circ} \mathrm{C}$.

Aliquots $(5 \mu \mathrm{L})$ of PCR products were mixed with $10 \mu \mathrm{L}$ denaturing solution $(95 \%$ deionized formamide, $5 \mathrm{mM}$ EDTA, $0.025 \%$ bromophenol blue, and $0.025 \%$ xylene-cyanole), heated at $98^{\circ} \mathrm{C}$ for $15 \mathrm{~min}$, immediately cooled on ice and placed at $-20^{\circ} \mathrm{C}$ for $5-10 \mathrm{~min}$. 
Equal amounts of denatured PCR products from the different samples were subjected to nondenaturing polyacrylamide gel electrophoresis on a 30\% gel acrylamide:bisacrylamide (29:1) at a constant voltage of $135 \mathrm{~V}$ for $13 \mathrm{~h}$. PCR-SSCP bands were finally genotyped after being stained with $0.1 \%$ silver nitrate and visualized with $2 \% \mathrm{NaOH}$ solution. Three samples from different genotypes were sequenced bi-directionally.

\section{Statistical analysis}

Relative levels of gene expression in various tissues were obtained using the $2^{-\Delta \Delta \mathrm{Ct}}$ method. Sequences were edited and SNP sites were screened using MEGA 6.0 software. Allele frequency, genotype frequency, chi-squared $\left(\chi^{2}\right)$, polymorphism information content (PIC), effective number of alleles $\left(N_{\mathrm{E}}\right)$, and heterozygosities $(\mathrm{h})$ were calculated by PopGen32 V1.31. General linear model procedures (SPSS 17.0) were used to analyze relationships between gene expression, genetic polymorphisms, and serum biochemical indices. Values were considered to be statistically significant at $\mathrm{P}<0.05$ and are reported as means \pm standard error.

\section{RESULTS}

\section{CD36 gene expression profile}

The level of $C D 36$ mRNA in 16 tissues of Cherry Valley duck (six male, six female) is presented in Figure 1. CD36 mRNA was expressed in all tested tissues obtained from 10 -week-old ducks. Among those, $C D 36$ was found to be highly expressed in the subcutaneous fat, pituitary, large intestine, and abdominal fat, followed by moderate expression in the hypothalamus and breast muscle. Low levels of mRNA were observed in the heart, liver, spleen, lung, kidney, proventriculus, gizzard, cerebellum, cerebrum, and intestine.

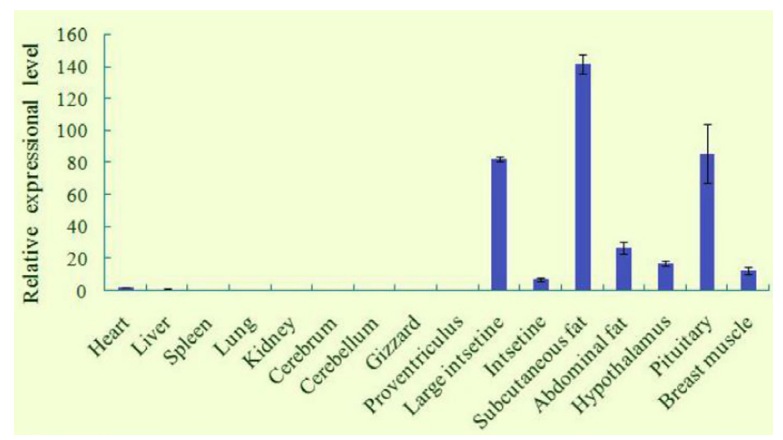

Figure 1. Expression profiles of duck CD36 mRNA in 16 tissues. Relative expression of $C D 36$ mRNA was analyzed using the comparative $\mathrm{Ct}$ method, employing duck $\beta$-actin as the reference gene.

\section{Characteristics of the CD36 g.476593 T > C SNP}

SSCP results indicated that a SNP, g.476593 T $>$ C, was located in exon 9 of the Cherry Valley duck CD36 gene. Genotype distribution and alleles of the mutant site were as follows: three genotypes, MM, MN, NN, and two alleles, M and N (Figure 2). Sequencing results 
(Figure 3) showed that the g.476593 $\mathrm{T}>\mathrm{C}$ mutation was silent and did not cause an amino acid change. Properties of the g.476593 T $>\mathrm{C}$ mutation are listed in Table 2. The dominant genotype and allele were $\mathrm{MM}$ and $\mathrm{M}$, with frequencies of 0.453 and 0.643 , respectively. Heterozygosity $(\mathrm{h})$ and effective number of alleles $\left(N_{\mathrm{E}}\right)$ were 0.459 and 1.849 , respectively. PIC of g.476593 T $>\mathrm{C}$ was 0.354 , indicating a moderate degree of polymorphism. Chi-square test implied that g.476593 $\mathrm{T}>\mathrm{C}$ locus deviated from Hardy-Weinberg equilibrium $(\mathrm{P}<0.01)$.

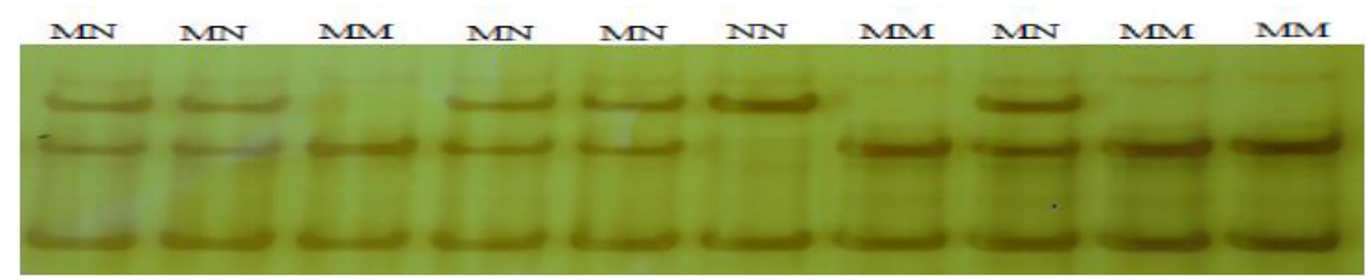

Figure 2. SSCP bands using primer CD7 (F2/R2) for Cherry Valley duck CD36.
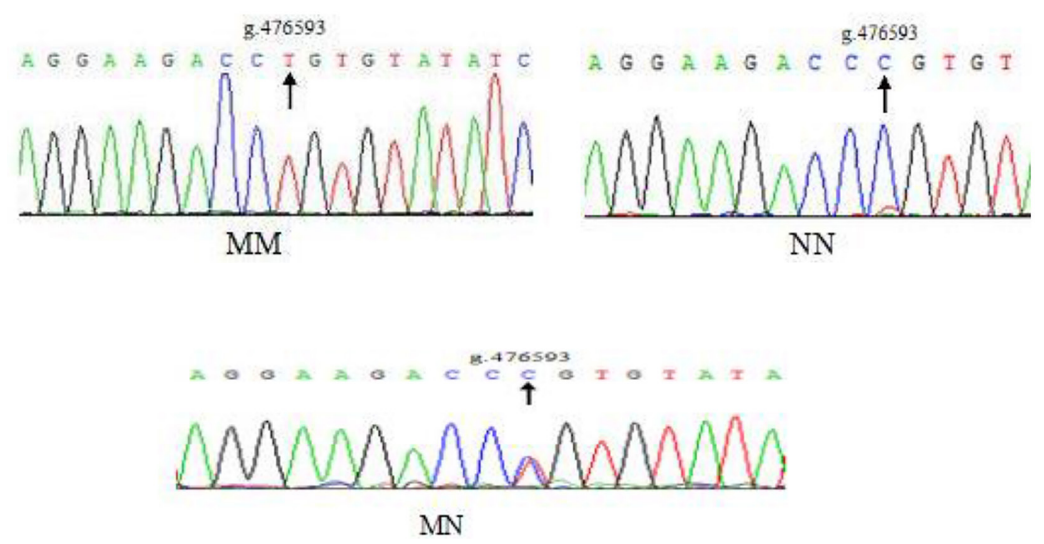

Figure 3. Sequencing results of Cherry Valley duck CD36 gene using primer CD7 (F2/R2).

Table 2. Genotype and allele frequencies of the CD36 gene g.476593 T > C locus in Cherry Valley duck.

\begin{tabular}{l|c|c|c|c|c|c|c|c|c}
\hline \multirow{2}{*}{ SNP locus } & \multicolumn{3}{|c|}{ Genotype frequency } & \multicolumn{2}{c|}{ Allele frequency } & $\mathrm{h}$ & $N_{\mathrm{E}}$ & PIC & $\chi^{2}(\mathrm{HWE})$ \\
\cline { 2 - 10 } & MM (43) & MN (36) & NN (16) & M & N & & & & \\
\hline g.476593 T $>$ C & 0.453 & 0.379 & 0.168 & 0.643 & 0.357 & 0.459 & 1.849 & 0.354 & 65.41 \\
\hline
\end{tabular}

$\mathrm{h}=$ heterozygosity; PIC = polymorphism information content; $\chi^{2}=$ Hardy-Weinberg equilibrium; $\chi^{2}{ }_{0.05(2)}=10.60$

\section{Correlation between $C D 36$ gene expression and serum biochemical indices}

Correlation analyses between $C D 36$ gene expression in the liver of ducks (53 males, 42 females) and serum biochemical indices are shown in Table 3. No significant correlations were found between serum high-density lipoprotein cholesterol, albumin, and CD36 mRNA levels. Additionally, CD36 expression was significantly positively correlated $(\mathrm{P}<0.01)$ with serum total protein, globulin, total cholesterol, and low-density lipoprotein cholesterol, and was inversely correlated $(\mathrm{P}<0.05)$ with triglycerides. 
Table 3. Expression of $C D 36$ and its correlation with serum biochemical level.

\begin{tabular}{l|l|c|c|c|c|c|c|c}
\hline Gene & Indices & TP $(\mathrm{g} / \mathrm{L})$ & ALB $(\mathrm{g} / \mathrm{L})$ & GLB $(\mathrm{g} / \mathrm{L})$ & TG $(\mathrm{mM})$ & TC $(\mathrm{mM})$ & HDL-C $(\mathrm{mM})$ & LDL-C (mM) \\
\hline$C D 36$ & Mean \pm SD & $35.276 \pm 0.834$ & $14.232 \pm 0.256$ & $21.044 \pm 0.677$ & $0.822 \pm 0.033$ & $5.179 \pm 0.118$ & $3.027 \pm 0.107$ & $1.779 \pm 0.050$ \\
\hline & $\begin{array}{l}\text { Correlation } \\
\text { coefficient }\end{array}$ & $0.384^{* *}$ & 0.067 & $0.447^{* *}$ & $-0.277^{*}$ & $0.327^{* *}$ & 0.064 & $0.420^{* *}$ \\
\hline
\end{tabular}

$\mathrm{TP}=$ total protein $; \mathrm{ALB}=$ albumin $; \mathrm{GLB}=$ globulin; $\mathrm{TG}=$ triglyceride $; \mathrm{TC}=$ total cholesterol; HDL-C $=$ high density lipoprotein cholesterol; LDL-C = low-density lipoprotein cholesterol. *Correlation is significant at the 0.05 level, **Correlation is significant at the 0.05 level.

\section{Association analysis between CD36 SNP (g.476593 T > C) and serum biochemical indices}

With the exception of TG, serum biochemical indicators were significantly different among the MM, MN, and NN genotypes $(\mathrm{P}<0.05)$. In addition, ducks carrying the $\mathrm{NN}$ genotype had higher globulin (GLB), total cholesterol (TC), low density lipoprotein cholesterol (LDL-C), and high density lipoprotein cholesterol (HDL-C) than ducks with the MM and MN genotypes $(\mathrm{P}<0.05$; Table 4$)$.

Table 4. Single nucleotide polymorphism g.476593 T $>$ C of $C D 36$ and its association with serum biochemistry.

\begin{tabular}{l|c|c|c}
\hline \multirow{2}{*}{ Indices } & \multicolumn{3}{|c}{ Genotype (Means \pm SD) } \\
\cline { 2 - 4 } & MM (43) & MN (36) & NN $(16)$ \\
\hline GLB $(\mathrm{g} / \mathrm{L})$ & $16.456 \pm 0.615^{\mathrm{a}}$ & $22.207 \pm 0.668^{\mathrm{b}}$ & $32.091 \pm 1.077^{\mathrm{c}}$ \\
\hline TP $(\mathrm{g} / \mathrm{L})$ & $29.202 \pm 0.736^{\mathrm{a}}$ & $37.385 \pm 0.799^{\mathrm{b}}$ & $48.4225 \pm 1.289^{\mathrm{c}}$ \\
\hline $\mathrm{ALB}(\mathrm{g} / \mathrm{L})$ & $12.752 \pm 0.316^{\mathrm{a}}$ & $15.172 \pm 0.343^{\mathrm{b}}$ & $16.34 \pm 0.554^{\mathrm{b}}$ \\
\hline TG $(\mathrm{mM})$ & $0.833 \pm 0.05$ & $0.838 \pm 0.054$ & $0.807 \pm 0.087$ \\
\hline TC $(\mathrm{mM})$ & $4.664 \pm 0.158^{\mathrm{a}}$ & $5.467 \pm 0.172^{\mathrm{b}}$ & $6.012 \pm 0.277^{\mathrm{b}}$ \\
\hline HDL-C $(\mathrm{mM})$ & $2.659 \pm 0.152^{\mathrm{a}}$ & $3.218 \pm 0.163^{\mathrm{b}}$ & $3.673 \pm 0.262^{\mathrm{b}}$ \\
\hline LDL-C $(\mathrm{mM})$ & $1.639 \pm 0.071^{\mathrm{a}}$ & $1.869 \pm 0.077^{\mathrm{b}}$ & $1.972 \pm 0.125^{\mathrm{b}}$ \\
\hline
\end{tabular}

$\mathrm{GLB}=$ globulin; $\mathrm{TP}=$ total protein; $\mathrm{ALB}=$ albumin; $\mathrm{TG}=$ triglyceride; $\mathrm{TC}=$ total cholesterol; HDL-C $=$ high density lipoprotein cholesterol; LDL-C = low density lipoprotein cholesterol. Values with different superscript letter in the same line are significantly difference $(\mathrm{P}>0.05)$.

\section{DISCUSSION}

Serum biochemical indicators are necessary for the maintenance of normal homeostasis in vivo and are used to evaluate livestock production, laying, and meat value. Thus, knowledge on serum biochemical parameters in poultry will facilitate the diagnosis of existing diseases and optimize the value of birds. CD36 is a metabolic enzyme that participates in lipid metabolism, and can be used as a candidate gene as its functional study has been an area of focus. Because CD36 alters glucose and lipid metabolism, CD36-null mice have been suggested as a model to dissect the interrelationship between fatty acid and glucose utilization and uptake. CD36 expression is decreased by IL-10 and interferon- $\gamma$, which potentially have anti-atherosclerotic and anti-obesity effects (Nakagawa et al., 1998; Rubic and Lorenz, 2006). However, an association between CD36 expression and polymorphisms with serum biochemical indices in Cherry Valley has not yet been documented. Considering the importance of $C D 36$, this study investigated serum biochemical parameters and their association with $C D 36$ gene expression and genetic variation.

These results showed that $C D 36 \mathrm{mRNA}$ is expressed in all tissues, with high expression found in the pituitary and large intestine, and in subcutaneous and abdominal fat, suggesting that $C D 36$ is tissue-specific. Abumrad et al. (1993) reported that CD36 was abundant in the 
intestine, spleen, and heart of rats, which differs from the results of the present study. In addition, the level of CD36 expression was low in the liver, which is mainly responsible for lipid synthesis and decomposition in poultry. The reasons for this is unknown and further study is warranted to explore the underlying mechanisms. Correlation analysis revealed that CD36 was positively correlated with LDL, which is similar to the findings of previous studies (Yamashita et al., 2007; Xie et al., 2011; Babaahmadi Rezaei et al., 2013). Goudriaan et al. (2005) observed an increase in TG levels in CD36 knockout mice, similar to the results of the present study. These findings indicate that lipoprotein is regulated by the level of $C D 36$ gene and protein expression, which subsequently affects cellular cholesterol levels. Therefore, it may be possible to obtain an advantageous duck breed with reduced $C D 36$ levels by reducing the level of LDL-C or increasing TG rather than slaughtering and determinating, which was attributed to reduction of lipid storage in vivo in the course of catabolism. In addition, a previous study revealed there was a negative correlation between CD36 and HDL-C in mice, suggesting that the $C D 36$ expression model was unique to each variety (Brundert et al., 2011). In summary, $C D 36$ may exert its biological functions by regulating the levels of serum biochemical parameters. However, the specific mechanism remains unclear and requires further clarification. Further studies on other candidate genes associated with serum biochemical indices are required to explore the interactions between candidate genes on serum biochemical indices. There is an urgent need for a better understanding of the characteristics of different duck varieties to facilitate diagnosis of diseases and improve the duck species. Moreover, it also exhibit an excellent duck species and lay a foundation for the selection of high quality duck.

Many studies have investigated SNPs in the human CD36 gene. For example, a study on $C D 36$ (rs1761667) showed that obese women carrying the GG genotype exhibit lower thresholds of gustatory mechanisms for fat detection than those with the AA genotype (Mrizak et al., 2015). In addition, the A allele of IVS4-10 G/A and the C allele of IVS3-6 T/C have both been associated with myocardial infarction (Rać et al., 2012b). Rać et al. (2012a) demonstrated that the GG genotype of CD36 was significantly correlated with higher concentrations of HbA1c compared with the AA genotype in obese children.

The results of the present study showed significantly different levels of serum protein among Cherry Valley duck carrying different genotypes of the CD36 gene SNP g.476593 T $>$ C . Serum biochemical indices, with the exception of triglycerides, were higher in the NN genotype group than in the MM group, which suggested that the duck group was likely to generate mutations and mutant duck group (NN) was more exuberant than wild type (MM) in lipid metabolism. Based on the function of CD36 in the regulation of body lipid metabolism, it was inferred that $C D 36$ gene expression and fatty acid catabolism in the mutant duck group was due to the g.476593 $\mathrm{T}>\mathrm{C}$ mutation in this species, resulting in higher serum biochemical indices than in the wild type duck group. The genotype distribution of the CD36 g.476593 $\mathrm{T}>\mathrm{C}$ SNP deviated from Hardy-Weinberg equilibrium, indicating that the Cherry Valley duck is likely to be influenced by long-term artificial selection. Furthermore, among the eight exons, only a single SNP was detected in this species, suggesting that the CD36 gene sequence might have been highly conserved through evolution, which is consistent with the findings of a previous study (Greenwalt et al., 1992). A search of online databases, including the NCBI, HighWire Press, and Web of Science, revealed this study to be the first to investigate the association between $C D 36$ polymorphisms and expression with serum biochemical indices in ducks. CD36 mRNA expression is highly tissue-specific. CD36 mRNA expression and the g.476593 T > C SNP in the duck CD36 gene were significantly associated with serum 
biochemical indices, which suggest that the $C D 36$ gene might be an important candidate gene for use in marker assisted selection to improve duck lipid metabolism and meat quality.

\section{Conflicts of interest}

The authors declare no conflict of interest.

\section{ACKNOWLEDGMENTS}

We are grateful to Vice Professor Yiyu Zhang for reviewing the manuscript. Research supported by grants from the National Natural Science Foundation of China (\#31160453).

\section{REFERENCES}

Abumrad NA, el-Maghrabi MR, Amri EZ, Lopez E, et al. (1993). Cloning of a rat adipocyte membrane protein implicated in binding or transport of long-chain fatty acids that is induced during preadipocyte differentiation. Homology with human CD36. J. Biol. Chem. 268: 17665-17668.

Allred KF, Smart EJ and Wilson ME (2006). Estrogen receptor-alpha mediates gender differences in atherosclerosis induced by HIV protease inhibitors. J. Biol. Chem. 281: 1419-1425. http://dx.doi.org/10.1074/jbc.M506046200

Babaahmadi Rezaei H, Doosti M, Aminian M and Shabani P (2013). Compare the effect of eicosapentaenoic acid and oxidized low-density lipoprotein on the expression of CD36 and peroxisome proliferator-activated receptor gamma. Iran. Biomed. J. 17: 84-92.

Bao Y, Wang L, Xu Y, Yang Y, et al. (2012). Salvianolic acid B inhibits macrophage uptake of modified low density lipoprotein (mLDL) in a scavenger receptor CD36-dependent manner. Atherosclerosis 223: 152-159. http://dx.doi. org/10.1016/j.atherosclerosis.2012.05.006

Brundert M, Heeren J, Merkel M, Carambia A, et al. (2011). Scavenger receptor CD36 mediates uptake of high density lipoproteins in mice and by cultured cells. J. Lipid Res. 52: 745-758. http://dx.doi.org/10.1194/jlr.M011981

Cheung L, Andersen M, Gustavsson C, Odeberg J, et al. (2007). Hormonal and nutritional regulation of alternative CD36 transcripts in rat liver--a role for growth hormone in alternative exon usage. BMC Mol. Biol. 8: 60. http://dx.doi. org/10.1186/1471-2199-8-60

Cho S (2012). CD36 as a therapeutic target for endothelial dysfunction in stroke. Curr. Pharm. Des. 18: 3721-3730. http:// dx.doi.org/10.2174/138161212802002760

Endemann G, Stanton LW, Madden KS, Bryant CM, et al. (1993). CD36 is a receptor for oxidized low density lipoprotein. J. Biol. Chem. 268: 11811-11816.

Febbraio M, Hajjar DP and Silverstein RL (2001). CD36: a class B scavenger receptor involved in angiogenesis, atherosclerosis, inflammation, and lipid metabolism. J. Clin. Invest. 108: 785-791. http://dx.doi.org/10.1172/ JCI14006

Forbes JM, Soldatos G and Thomas MC (2005). Below the radar: advanced glycation end products that detour "around the side". Is HbA1c not an accurate enough predictor of long term progression and glycaemic control in diabetes? Clin. Biochem. Rev. 26: 123-134.

Goudriaan JR, den Boer MA, Rensen PC, Febbraio M, et al. (2005). CD36 deficiency in mice impairs lipoprotein lipasemediated triglyceride clearance. J. Lipid Res. 46: 2175-2181.http://dx.doi.org/10.1194/jlr.M500112-JLR200

Greenwalt DE, Lipsky RH, Ockenhouse CF, Ikeda H, et al. (1992). Membrane glycoprotein CD36: a review of its roles in adherence, signal transduction, and transfusion medicine. Blood 80: 1105-1115.

Huh HY, Pearce SF, Yesner LM, Schindler JL, et al. (1996). Regulated expression of CD36 during monocyte-tomacrophage differentiation: potential role of CD36 in foam cell formation. Blood 87: 2020-2028.

Kolak M, Yki-Järvinen H, Kannisto K, Tiikkainen M, et al. (2007). Effects of chronic rosiglitazone therapy on gene expression in human adipose tissue in vivo in patients with type 2 diabetes. J. Clin. Endocrinol. Metab. 92: 720-724. http://dx.doi.org/10.1210/jc.2006-1465

Kwok CF, Juan CC and Ho LT (2007). Endothelin-1 decreases CD36 protein expression in vascular smooth muscle cells. Am. J. Physiol. Endocrinol. Metab. 292: E648-E652.http://dx.doi.org/10.1152/ajpendo.00084.2006

Llaverias G, Rebollo A, Pou J, Vázquez-Carrera M, et al. (2006). Effects of rosiglitazone and atorvastatin on the expression of genes that control cholesterol homeostasis in differentiating monocytes. Biochem. Pharmacol. 71: 605-614. http:// dx.doi.org/10.1016/j.bcp.2005.11.022 
Love-Gregory L, Sherva R, Schappe T, Qi JS, et al. (2011). Common CD36 SNPs reduce protein expression and may contribute to a protective atherogenic profile. Hum. Mol. Genet. 20: 193-201. http://dx.doi.org/10.1093/hmg/ddq449

McFarlan JT, Yoshida Y, Jain SS, Han XX, et al. (2012). In vivo, fatty acid translocase (CD36) critically regulates skeletal muscle fuel selection, exercise performance, and training-induced adaptation of fatty acid oxidation. J. Biol. Chem. 287: 23502-23516.http://dx.doi.org/10.1074/jbc.M111.315358

Mrizak I, Šerý O, Plesnik J, Arfa A, et al. (2015). The A allele of cluster of differentiation 36 (CD36) SNP 1761667 associates with decreased lipid taste perception in obese Tunisian women. Br. J. Nutr. 113: 1330-1337.http://dx.doi. org $/ 10.1017 / \mathrm{S} 0007114515000343$

Nakagawa T, Nozaki S, Nishida M, Yakub JM, et al. (1998). Oxidized LDL increases and interferon-gamma decreases expression of CD36 in human monocyte-derived macrophages. Arterioscler. Thromb. Vasc. Biol. 18: 1350-1357. http://dx.doi.org/10.1161/01.ATV.18.8.1350

Nergiz-Unal R, Rademakers T, Cosemans JM and Heemskerk JW (2011). CD36 as a multiple-ligand signaling receptor in atherothrombosis. Cardiovasc. Hematol.Agents Med.Chem.9:42-55.http://dx.doi.org/10.2174/187152511794182855

Pepino MY, Kuda O, Samovski D and Abumrad NA (2014). Structure-function of CD36 and importance of fatty acid signal transduction in fat metabolism. Annu. Rev. Nutr. 34: 281-303. http://dx.doi.org/10.1146/annurevnutr-071812-161220

Prieto J, Eklund A and Patarroyo M (1994). Regulated expression of integrins and other adhesion molecules during differentiation of monocytes into macrophages. Cell. Immunol. 156: 191-211. http://dx.doi.org/10.1006/ cimm.1994.1164

Primeaux SD, Braymer HD and Bray GA (2013). CD36 mRNA in the gastrointestinal tract is differentially regulated by dietary fat intake in obesity-prone and obesity-resistant rats. Dig. Dis. Sci. 58: 363-370. http://dx.doi.org/10.1007/ $\underline{\text { s10620-012-2364-4 }}$

Rać ME, Krupa B, Garanty-Bogacka B, Syrenicz M, et al. (2012a). Polymorphism of CD36 gene, carbohydrate metabolism and plasma CD36 concentration in obese children. A preliminary study. Postepy Hig Med Dosw (Online) 66: $954-$ 958. http://dx.doi.org/10.5604/17322693.1021112

Rać ME, Suchy J, Kurzawski G, Kurlapska A, et al. (2012b). Polymorphism of the CD36 gene and cardiovascular risk factors in patients with coronary artery disease manifested at a young age. Biochem. Genet. 50: 103-111. http:// dx.doi.org/10.1007/s10528-011-9475-z

Rubic T and Lorenz RL (2006). Downregulated CD36 and oxLDL uptake and stimulated ABCA1/G1 and cholesterol efflux as anti-atherosclerotic mechanisms of interleukin-10. Cardiovasc. Res. 69: 527-535. http://dx.doi.org/10.1016/j. cardiores.2005.10.018

Ryeom SW, Silverstein RL, Scotto A and Sparrow JR (1996). Binding of anionic phospholipids to retinal pigment epithelium may be mediated by the scavenger receptor CD36. J. Biol. Chem. 271: 20536-20539. http://dx.doi. org/10.1074/jbc.271.34.20536

Silverstein RL and Febbraio M (2009). CD36, a scavenger receptor involved in immunity, metabolism, angiogenesis, and behavior. Sci. Signal. 2: re3. http://dx.doi.org/10.1126/scisignal.272re3

Xie C, Ng H and Nagarajan S (2011). OxLDL or TLR2-induced cytokine response is enhanced by oxLDL-independent novel domain on mouse CD36. Immunol. Lett. 137: 15-27. http://dx.doi.org/10.1016/j.imlet.2011.01.015

Yamashita S, Hirano K, Kuwasako T, Janabi M, et al. (2007). Physiological and pathological roles of a multi-ligand receptor CD36 in atherogenesis; insights from CD36-deficient patients. Mol. Cell. Biochem. 299: 19-22. http:// dx.doi.org/10.1007/s11010-005-9031-4 